\title{
Organonitrile ligated silver complexes with perfluorinated weakly coordinating anions and their catalytic application for coupling reactions
}

\author{
Yanmei Zhang, ${ }^{a}$ Ana M. Santos, ${ }^{a}$ Eberhardt Herdtweck, ${ }^{a}$ Janos Mink ${ }^{b c}$ and Fritz E. Kühn ${ }^{* a}$ \\ ${ }^{a}$ Anorganisch-chemisches Institut der Technischen Universität München, Lichtenbergstraße 4, \\ D-85747 Garching bei München, Germany.E-mail: fritz.kuehn@ch.tum.de \\ ${ }^{\boldsymbol{b}}$ Molecular Spectroscopy Department, Chemical Research Centre of the Hungarian \\ Academy of Sciences, PO Box 17, H-1525 Budapest, Hungary \\ ${ }^{c}$ Analytical Chemistry Research Group of the Hungarian Academy of Sciences, \\ Veszprém University PO Box 158, H-8201 Veszpém, Hungary
}

Received (in Durham, UK) 13th September 2004, Accepted 17th December 2004

First published as an Advance Article on the web 17th January 2005

Homogeneous catalytic processes mediated by silver(I) complexes are relatively rare. This work describes the synthesis and characterization of acetonitrile ligated silver salts with three weakly coordinating anions $\left[\mathrm{B}\left(\mathrm{C}_{6} \mathrm{~F}_{5}\right)_{4}\right]^{-},\left[\mathrm{B}\left\{\mathrm{C}_{6} \mathrm{H}_{3}\left(\mathrm{CF}_{3}\right)_{2}\right\}_{4}\right]^{-}$and $\left[\left(\mathrm{C}_{6} \mathrm{~F}_{5}\right)_{3} \mathrm{~B}-\mathrm{C}_{3} \mathrm{H}_{4} \mathrm{~N}_{2}-\mathrm{B}\left(\mathrm{C}_{6} \mathrm{~F}_{5}\right)_{3}\right]^{-}$. The silver cation is coordinated either by four or by two acetonitrile ligands. All examined $\mathrm{Ag}(\mathrm{I})$ complexes show catalytic activity in coupling reactions of terminal alkynes with aldehydes and amines.

\section{Introduction}

Coordination chemistry has made extensive use of non-coordinating and weakly coordinating anions. Some of the weakly coordinating, fluorine-containing anions such as $\mathrm{BF}_{4}{ }^{-}, \mathrm{PF}_{6}{ }^{-}$, $\mathrm{SO}_{3} \mathrm{CF}_{3}{ }^{-}, \mathrm{B}\left(\mathrm{C}_{6} \mathrm{~F}_{5}\right)_{4}{ }^{-}, \mathrm{OTeF}_{5}^{-}$, etc. play a significant role in chemistry. ${ }^{1}$ Their large size frequently aids the stabilization of complex cations, ${ }^{2}$ and their weak coordination mode allows the introduction of other (somewhat less) weakly coordinating ligands ${ }^{3}$ or the creation of vacant coordination sites and virtually "naked" metal atoms. ${ }^{4}$

In spite of the fact that heterogeneous silver-catalyzed olefin epoxidation is one of the most important and thoroughly investigated industrial processes, ${ }^{5}$ homogeneous catalytic processes mediated by silver(I) are relatively rare. Reports on silver(I)-catalyzed processes include carbon-hydrogen insertion, ${ }^{6}$ carbon-halogen bond activation, ${ }^{7}$ aziridination, ${ }^{8}$ silacyclopropanation, ${ }^{9}$ ketone-hydroxylation reactions, ${ }^{10}$ cyclopropanation $^{11}$ and propargylic amine synthesis. ${ }^{12}$

Silver ions with weakly coordinating anions are normally used as metathesis reagents and starting materials for the synthesis of asymmetric catalysts ${ }^{13}$ and supramolecules. ${ }^{14} \mathrm{~A}$ recent investigation showed $\left[\mathrm{Ag}\left(\mathrm{PPh}_{3}\right)\right]^{+}\left[\mathrm{CB}_{11} \mathrm{H}_{6} \mathrm{Br}_{6}\right]^{-}$to be air and moisture stable as well as to be the best catalyst for a series of hetero Diels-Alder reactions. ${ }^{15}$ Recently Li et al. ${ }^{16}$ as well as other groups ${ }^{17}$ have described the direct addition of terminal alkynes to aldehydes and amines to afford propargyl alcohols and propargyl amines. In this paper, we report the synthesis and characterization of nitrile ligated silver salts with three types of weakly coordinating anions and their catalytic activity towards the coupling reaction of terminal alkynes with aldehydes and amines. The applied weakly coordinated anions are $\left[\mathrm{B}\left(\mathrm{C}_{6} \mathrm{~F}_{5}\right)_{4}\right]^{-}$, $\left[\mathrm{B}\left\{\mathrm{C}_{6} \mathrm{H}_{3}\left(\mathrm{CF}_{3}\right)_{2}\right\}_{4}\right]^{-}$and $\left[\left(\mathrm{C}_{6} \mathrm{~F}_{5}\right)_{3} \mathrm{~B}-\mathrm{C}_{3} \mathrm{H}_{4} \mathrm{~N}_{2}-\mathrm{B}\left(\mathrm{C}_{6} \mathrm{~F}_{5}\right)_{3}\right]^{-}$.

\section{Results and discussion}

Synthesis and characterization

$\operatorname{Ag}\left[\mathrm{B}\left(\mathrm{C}_{6} \mathrm{~F}_{5}\right)_{4}\right]$ and $\mathrm{Ag}\left[\mathrm{B}\left\{\mathrm{C}_{6} \mathrm{H}_{3}\left(\mathrm{CF}_{3}\right)_{2}\right\}_{4}\right]$ were prepared by reacting pentafluorobenzene bromide and 3,5-bis(trifluoromethyl)- bromobenzene with $n$-butyllithium in diethyl ether at $-78{ }^{\circ} \mathrm{C}$; after reacting for $c a .30$ min $\mathrm{BCl}_{3}$ was added. The reaction mixture was then brought to room temperature and the potassium salts were obtained by adding potassium chloride. The potassium was subsequently exchanged by silver through the addition of silver nitrate. $\mathrm{K}\left[\left(\mathrm{C}_{6} \mathrm{~F}_{5}\right)_{3} \mathrm{~B}-\mathrm{C}_{3} \mathrm{H}_{4} \mathrm{~N}_{2}-\mathrm{B}\left(\mathrm{C}_{6} \mathrm{~F}_{5}\right)_{3}\right]$ was synthesized according to a literature procedure ${ }^{18}$ and converted into the corresponding silver salt by exchange with silver nitrate.

$\mathrm{Ag}\left[\mathrm{B}\left(\mathrm{C}_{6} \mathrm{~F}_{5}\right)_{4}\right]$ and $\mathrm{Ag}\left[\left(\mathrm{C}_{6} \mathrm{~F}_{5}\right)_{3} \mathrm{~B}-\mathrm{C}_{3} \mathrm{H}_{4} \mathrm{~N}_{2}-\mathrm{B}\left(\mathrm{C}_{6} \mathrm{~F}_{5}\right)_{3}\right]$ were recrystallized in acetonitrile at $-35{ }^{\circ} \mathrm{C}$ yielding crystalline, tetrahedrally coordinated $\left[\mathrm{Ag}\left(\mathrm{NCCH}_{3}\right)_{4}\right]\left[\mathrm{B}\left(\mathrm{C}_{6} \mathrm{~F}_{5}\right)_{4}\right]$ (1) and $\left[\mathrm{Ag}\left(\mathrm{NCCH}_{3}\right)_{4}\right]\left[\left(\mathrm{C}_{6} \mathrm{~F}_{5}\right)_{3} \mathrm{~B}-\mathrm{C}_{3} \mathrm{H}_{4} \mathrm{~N}_{2}-\mathrm{B}\left(\mathrm{C}_{6} \mathrm{~F}_{5}\right)_{3}\right]$ (3) complexes (Chart 1). The X-ray crystal structure of complex 1 has been reported previously. ${ }^{19}$ The silver salt of $\left.\mathrm{B}\left\{\mathrm{C}_{6} \mathrm{H}_{3}\left(\mathrm{CF}_{3}\right)_{2}\right\}_{4}\right]$ is more difficult to crystallize. The recrystallization of it in
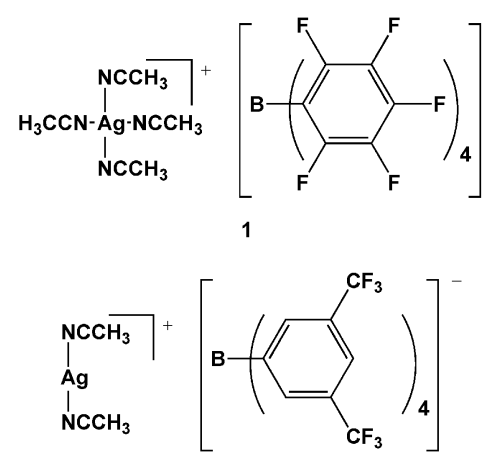

2

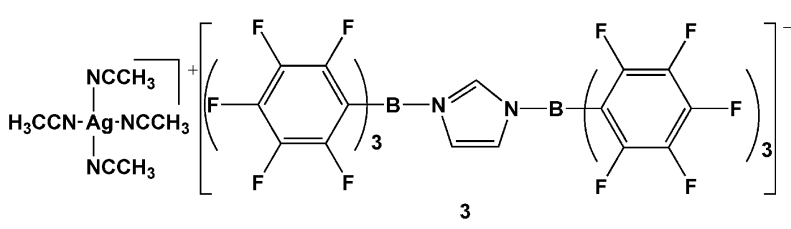

Chart 1 Complexes 1-3. 


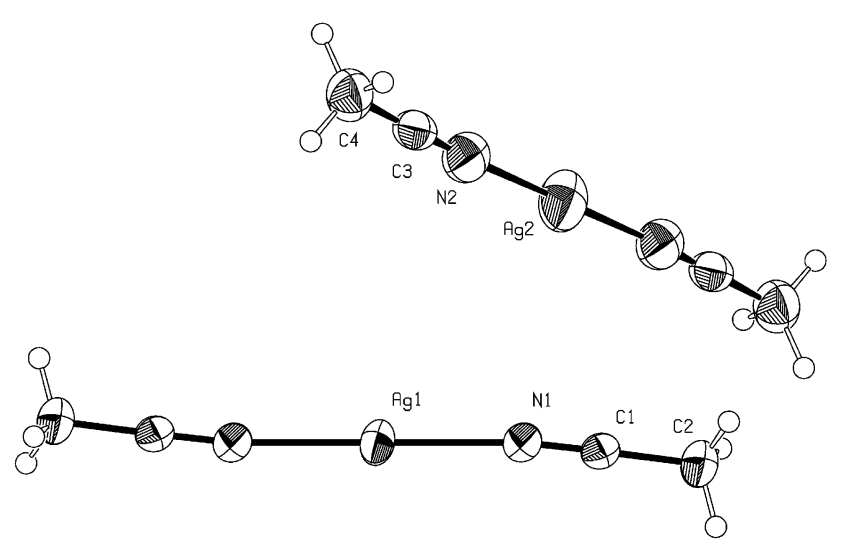

Fig. 1 ORTEP style plot of the cationic part of compound $\mathbf{2}$ in the solid state. Both molecules, $\mathbf{A}$ and $\mathbf{B}$, are located on a centre of symmetry. Thermal ellipsoids are drawn at a $50 \%$ probability level.

acetonitrile did not result in the isolation of the expected tetrahedrally coordinated $\mathrm{Ag}(\mathrm{I})$ complex. Only an oily product could be obtained that was, however, successfully recrystallized from a dichloromethane- $n$-hexane solution, yielding $\left[\mathrm{Ag}\left(\mathrm{NCCH}_{3}\right)_{2}\right]\left[\mathrm{B}\left\{\mathrm{C}_{6} \mathrm{H}_{3}\left(\mathrm{CF}_{3}\right)_{2}\right\}_{4}\right](2)$, bearing only two acetonitrile ligands according to elemental analysis.

The molecular structure of compound 2 (Fig. 1) was determined by single-crystal X-ray crystallography. $\dagger$ The key bond distances and angles are listed in Table 1 . The silver atoms appear linearly coordinated. The bond distances for $\mathrm{Ag}-\mathrm{N}$ in complex $\mathbf{2}$ are $c a .20 \mathrm{pm}$ shorter than those of complex $\mathbf{1}$ where $\mathrm{Ag}$ is tetrahedrally surrounded by acetonitrile ligands (Table $2)$. In the case of closely related $\mathrm{Cu}(\mathrm{I})$ complexes similar observations were made. ${ }^{20}$ The linearly coordinated $\left[\mathrm{Cu}\left(\mathrm{NCCH}_{3}\right)_{2}\right]^{+}$compounds display significantly shorter $\mathrm{M}-\mathrm{N}$ bonds than observed in tetrahedrally coordinated $\left[\mathrm{Cu}\left(\mathrm{NCCH}_{3}\right)_{4}\right]^{+}$, where the $\mathrm{Cu}-\mathrm{N}$ bonds are $c a .0 .15 \AA$ longer than in the linear $\mathrm{Cu}$ compound. ${ }^{20}$ Interestingly, the $\mathrm{B}\left(\mathrm{C}_{6} \mathrm{~F}_{5}\right)_{4}{ }^{-}$ counter ion, allowing a linear coordination of the $\mathrm{Cu}$ atom by $\mathrm{NCCH}_{3}$ molecules, does not permit such a coordination in the $\mathrm{Ag}(\mathrm{I})$ case as seen by the tetrahedral coordination of complex 1. While in the case of $\left[\mathrm{Cu}\left(\mathrm{NCCH}_{3}\right)_{2}\right]\left[\mathrm{B}\left(\mathrm{C}_{6} \mathrm{~F}_{5}\right)_{4}\right]$ a weak fluorine$\mathrm{Cu}$ interaction can be found $(\mathrm{F}-\mathrm{Cu}=271 \mathrm{pm}),{ }^{20}$ the distance between $\mathrm{Ag}$ and $\mathrm{F}$ is $313 \mathrm{pm}$ in the case of compound 2 and therefore nearly identical with the sum of the van der Waals radii $(319 \mathrm{pm})$ of $\mathrm{Ag}$ and $\mathrm{F}$. In the $\mathrm{Cu}-\mathrm{F}$ case the sum of the van der Waals radii amounts to $287 \mathrm{pm}$. In the case of the $\mathrm{Cu}$ complexes the bond length difference between linear and tetrahedral $\mathrm{Cu}-\mathrm{N}$ bonds is $c a$. $15 \mathrm{pm}$. We were not able to isolate an "intermediate" compound, where the $\mathrm{Ag}(\mathrm{I})$ ion is coordinated by three acetonitrile ligands. The same inability has been reported for the closely related $\mathrm{Cu}$ compounds. ${ }^{20}$

The results presented here demonstrate the ease of acetonitrile ligand removal once again (as had been observed already for related $\mathrm{Ag}(\mathrm{I})$ complexes $^{21}$ ), by showing the structures of an acetonitrile rich and an acetonitrile poor compound. Most interestingly, in both cases of compound $\mathbf{1}$ and of compound 2, no interaction with the counter ion is observed, which contrasts the linearly coordinated $\mathrm{Cu}$ case.

$\dagger \mathrm{C}_{36} \mathrm{H}_{18} \mathrm{AgBF}_{24} \mathrm{~N}_{2}, M_{\mathrm{r}}=1053.20$, data collected at $123 \mathrm{~K}$, colorless fragment $(0.38 \times 0.43 \times 0.81 \mathrm{~mm})$, triclinic, $P \overline{1}$ (No. 2), $a=12.6083(1)$, $b=12.8156(1), c=13.7369(1) \AA, \alpha=75.0063(4), \beta=76.7008(4), \gamma=$ 64.5828(4) ${ }^{\circ}, V=1918.45(3) \AA^{3}, D_{\mathrm{c}}=1.823 \mathrm{~cm}^{-3}, Z=2, \mu=0.674$ $\mathrm{mm}^{-1}$, reflections collected 39206 , independent reflections $7026\left(R_{\text {int }}=\right.$ $0.042)$, observed reflections $(I>2 \sigma(I))=5921$, data/restraints/parameters 7026/0/678, $R 1$ (observed/all data) $0.0369 / 0.0467, w R 2$ (observed/all data) $0.0886 / 0.0940$, GOF (observed/all data) $1.022 / 1.022$ CCDC reference number 258315. See http://www.rsc.org/suppdata/nj/ b4/b414060e/ for crystallographic data in .cif or other electronic format.
Table 1 Selected bond lengths ( $)$ and angles (deg) for complex 2

\begin{tabular}{llll}
\hline $\operatorname{Ag}(1)-\mathrm{N}(1)$ & $2.097(2)$ & $\mathrm{N}(1)-\operatorname{Ag}(1)-\mathrm{N}\left(1 \_\mathrm{a}\right)$ & 180 \\
$\operatorname{Ag}(2)-\mathrm{N}(2)$ & $2.066(4)$ & $\mathrm{N}(2)-\operatorname{Ag}(2)-\mathrm{N}\left(2 \_b\right)$ & 180 \\
& & $\operatorname{Ag}(1)-\mathrm{N}(1)-\mathrm{C}(1)$ & $171.9(3)$ \\
& & $\operatorname{Ag}(2)-\mathrm{N}(2)-\mathrm{C}(3)$ & $177.2(3)$ \\
\hline
\end{tabular}

Complexes $\mathbf{1}-\mathbf{3}$ were additionally characterized by elemental analysis, IR and ${ }^{1} \mathrm{H}$ NMR spectroscopy.

The shifts corresponding to the $\nu_{\mathrm{CN}}$ adsorption ( $\mathrm{CN}$ asymmetric stretching vibration) in the IR spectra are changed from $2266.5 \mathrm{~cm}^{-1}$ for gaseous $\mathrm{CH}_{3} \mathrm{CN}$ to $2286 \mathrm{~cm}^{-1}, 2296 \mathrm{~cm}^{-1}$ and $2285 \mathrm{~cm}^{-1}$ for complexes $\mathbf{1}, \mathbf{2}$ and $\mathbf{3}$, respectively. While the $\nu_{\mathrm{CN}}$ adsorptions in the tetrahedrally coordinated compounds $\mathbf{1}$ and 3 are identical within the error range, the same band for compound $\mathbf{2}$ is observed $10 \mathrm{~cm}^{-1}$ higher. The CN stretching frequency shifts for all examined complexes, leading to a considerable increase of the $\mathrm{CN}$ stretching force constants of compounds 1 and 3 to $c a .19 \mathrm{~N} \mathrm{~cm}^{-1}$ as compared to those of the free acetonitrile of $17.5 \mathrm{~N} \mathrm{~cm}^{-1}$. In the case of complex 2 the force constant increases even more. These observations are in good accord with what has been reported previously for related $\mathrm{Cu}(\mathrm{I})$ complexes. ${ }^{20}$

The ${ }^{1} \mathrm{H}$ NMR shifts corresponding to the methyl group of acetonitrile (measured in methylene chloride) were observed $2.07 \mathrm{ppm}, 2.03 \mathrm{ppm}$ and $1.87 \mathrm{ppm}$ for complexes $\mathbf{1 , 2}$ and $\mathbf{3}$, respectively, slightly shifted to low field in comparison to $\mathrm{CH}_{3} \mathrm{CN}$ (1.83). In this case, however, no clear difference in the chemical shift of the $\mathrm{CH}_{3}$ protons of the linearly coordinated compound $\mathbf{2}$ in comparison to the tetrahedrally coordinated compounds $\mathbf{1}$ and $\mathbf{3}$ can be observed.

\section{Thermogravimetry/mass spectrometry}

Complex 1 shows its first decomposition onset at $80{ }^{\circ} \mathrm{C}$, being a mass loss of $c a .10 \%$. Since an analogous decomposition step can not be found in acetonitrile free $\mathrm{K}\left[\mathrm{B}\left(\mathrm{C}_{6} \mathrm{~F}_{5}\right)_{4}\right]$, it must correspond to the loss of two acetonitrile ligands, amounting to $8.62 \%$ of the total mass of compound $\mathbf{1}$. This interpretation is further supported by mass spectroscopy (MS) of the fragments observed during the decomposition process (TG-MS). In the first decomposition steps no fluorine or $\mathrm{CF}$ containing fragments but extensive amounts of $\mathrm{CN}$ and $\mathrm{CH}_{3}$ containing fragments are detected. The second decomposition step starts at $130{ }^{\circ} \mathrm{C}$ and corresponds to a mass loss of $c a .60 \%$ of the original mass. Since $\mathrm{K}\left[\mathrm{B}\left(\mathrm{C}_{6} \mathrm{~F}_{5}\right)_{4}\right]$ shows a mass loss of $50 \%$ starting at approximately the same temperature it can be argued that this decomposition step accounts for anion fragmentation as well as the loss of two additional acetonitrile molecules $(8.62 \%)$. In the second step fragments of both the nitrile ligands and $\mathrm{CF}$ containing moieties are found by MS spectroscopy. The last decomposition step at $270{ }^{\circ} \mathrm{C}$ associated with $c a .10 \%$ mass loss in the case of complex 1 also occurs in $\mathrm{K}\left[\mathrm{B}\left(\mathrm{C}_{6} \mathrm{~F}_{5}\right)_{4}\right]$ at the same temperature and the same, fluorine containing fragments are found and therefore can be assigned to further anion degradation. Compound $\mathbf{2}$ shows a higher thermal stability than compound $\mathbf{1}$ (decomposition starting at $140{ }^{\circ} \mathrm{C}$ ) and decomposes in only one step. Since only two acetonitrile molecules are bonded to the metal, one can argue, in good agreement with the X-ray results, that these two

Table 2 Selected bond lengths $(\AA)$ and angles (deg) for complex 1

\begin{tabular}{lllr}
\hline $\mathrm{Ag}-\mathrm{N}(1)$ & $2.281(3)$ & $\mathrm{N}(1)-\mathrm{Ag}-\mathrm{N}(2)$ & $103.43(12)$ \\
$\mathrm{Ag}-\mathrm{N}(2)$ & $2.265(3)$ & $\mathrm{N}(1)-\mathrm{Ag}-\mathrm{N}(3)$ & $125.53(12)$ \\
$\mathrm{Ag}-\mathrm{N}(3)$ & $2.279(3)$ & $\mathrm{N}(1)-\mathrm{Ag}-\mathrm{N}(4)$ & $98.77(12)$ \\
$\mathrm{Ag}-\mathrm{N}(4)$ & $2.298(3)$ & $\mathrm{N}(2)-\mathrm{Ag}-\mathrm{N}(3)$ & $107.29(12)$ \\
& & $\mathrm{N}(2)-\mathrm{Ag}-\mathrm{N}(4)$ & $124.86(12)$ \\
& & $\mathrm{N}(3)-\mathrm{Ag}-\mathrm{N}(4)$ & $99.00(12)$ \\
\hline
\end{tabular}


remaining nitriles are more strongly bound than the nitrile ligands in compound $\mathbf{1}$ and that their displacement occurs concomitantly with the degradation and loss of the anion. The mass loss is finished at $270{ }^{\circ} \mathrm{C}$ with a residual value of $12 \%$. Compound 2 contains $10.24 \% \mathrm{Ag}$, which contributes, also according to EA of the residue, the bulk of the remaining material.

Astonishingly, compound $\mathbf{3}$ displays the highest thermal stability of the $\mathrm{Ag}$ and $\mathrm{K}$ complexes examined here. The presence of the acetonitrile stabilized silver cation seemingly even increases the stability of the complex in comparison to the precursor complex $\mathrm{K}\left[\left(\mathrm{C}_{6} \mathrm{~F}_{5}\right)_{3} \mathrm{~B}-\mathrm{C}_{3} \mathrm{H}_{4} \mathrm{~N}_{2}-\mathrm{B}\left(\mathrm{C}_{6} \mathrm{~F}_{5}\right)_{3}\right]$. This latter complex displays its first decomposition step at $c a .120{ }^{\circ} \mathrm{C}$. In the case of compound 3 two decomposition steps can be observed with onsets at $200{ }^{\circ} \mathrm{C}$ and $340{ }^{\circ} \mathrm{C}$ and associated with mass losses of 35 and $30 \%$, respectively, which can be assigned to anion decomposition and to the loss of the acetonitriles ( $12 \%$ of the original mass). The $\mathrm{C}_{6} \mathrm{~F}_{5}$ groups contribute $74 \%$ to the total mass of compound $\mathbf{3}$ and can therefore be only partially lost during these decomposition steps. However, the loss of the fluorine containing fragments takes place in both decomposition steps according to MS. $\mathrm{K}\left[\left(\mathrm{C}_{6} \mathrm{~F}_{5}\right)_{3} \mathrm{~B}-\mathrm{C}_{3} \mathrm{H}_{4} \mathrm{~N}_{2}-\right.$ $\left.\mathrm{B}\left(\mathrm{C}_{6} \mathrm{~F}_{5}\right)_{3}\right]$ shows three decomposition steps with onsets at $c a$. $120{ }^{\circ} \mathrm{C}, 300{ }^{\circ} \mathrm{C}$ and $480{ }^{\circ} \mathrm{C}$. All three steps are associated with the loss of $\mathrm{F}$ containing fragments, according to MS.

\section{Catalysis of coupling reactions with complexes 1-3}

Complexes 1-3 were found to be effective catalysts for the three-component coupling reaction of phenylacetylene, aldehydes and amines to generate propargylamines in toluene [eqn. (1)]. The catalytic reactions were performed without using any co-catalysts or additives. Phenylacetylene was coupled with several aldehydes and dialkylamines, the results being summarized in Table 3 and Chart 2. Both aromatic and aliphatic aldehydes were found to undergo addition reactions to afford the corresponding three-component propargylic amines effectively. The coupling reaction was highly affected by the nature of aldehydes, for instance the use of 2-pyridine aldehyde led to the lowest conversion obtained in this work. Complexes 1-3 show a similar catalytic behavior as can be seen by comparing entries 13, 15, 18 and 10, 16, 17. The lower yield obtained for

Table 3 Coupling of aldehydes, phenylacetylene and amines catalyzed by the silver(I) complexes (1-3) in toluene

\begin{tabular}{llll}
\hline Entry $^{a}$ & Aldehyde & Amine & Yield $(\%)^{b}$ \\
\hline $\mathbf{1}$ & $\mathrm{PhCHO}$ & Piperidine & 96 \\
$\mathbf{2}$ & $\mathrm{Ph}\left(\mathrm{CH}_{2}\right)_{2} \mathrm{CHO}$ & Piperidine & 92 \\
$\mathbf{3}$ & $p$-MePhCHO & Piperidine & 87 \\
$\mathbf{4}$ & $o$-MePhCHO & Piperidine & 96 \\
$\mathbf{5}$ & $c$ - ${ }_{6} \mathrm{H}_{11} \mathrm{CHO}$ & Piperidine & 98 \\
$\mathbf{6}$ & $p$-MeOPhCHO & Piperidine & 80 \\
$\mathbf{7}$ & $p$-CF ${ }_{3} \mathrm{PhCHO}$ & Piperidine & 91 \\
$\mathbf{8}$ & $m$-MePhCHO & Piperidine & 90 \\
$\mathbf{9}$ & $p-\mathrm{MePhCHO}$ & Pyrrolidine & 95 \\
$\mathbf{1 0}$ & $o$-MePhCHO & 4-Me-piperidine & 85 \\
$\mathbf{1 1}$ & 2-PyCHO & Pyrrolidine & 41 \\
$\mathbf{1 2}$ & $o$-MePhCHO & Pyrrolidine & 98 \\
$\mathbf{1 3}$ & $p$-MePhCHO & 4-Me-piperidine & 93 \\
$\mathbf{1 4}$ & $p$-MePhCHO & 4-Me-piperidine & $94^{c}$ \\
$\mathbf{1 5}$ & $p$-MePhCHO & 4-Me-piperidine & 82 \\
$\mathbf{1 6}$ & $o-\mathrm{MePhCHO}$ & Pyrrolidine & 95 \\
$\mathbf{1 7}$ & $o$-MePhCHO & Pyrrolidine & 91 \\
$\mathbf{1 8}$ & $p$-MePhCHO & 4-Me-piperidine & 90
\end{tabular}

${ }^{a}$ Entries 1-14 were catalyzed by 1 . Entries $15-16$ were catalyzed by 2 . Entries $17-18$ were catalyzed by $3 .{ }^{b}$ Yields were determined based on aldehyde. ${ }^{c}$ Using $0.3 \%$ of $\mathbf{1}$.

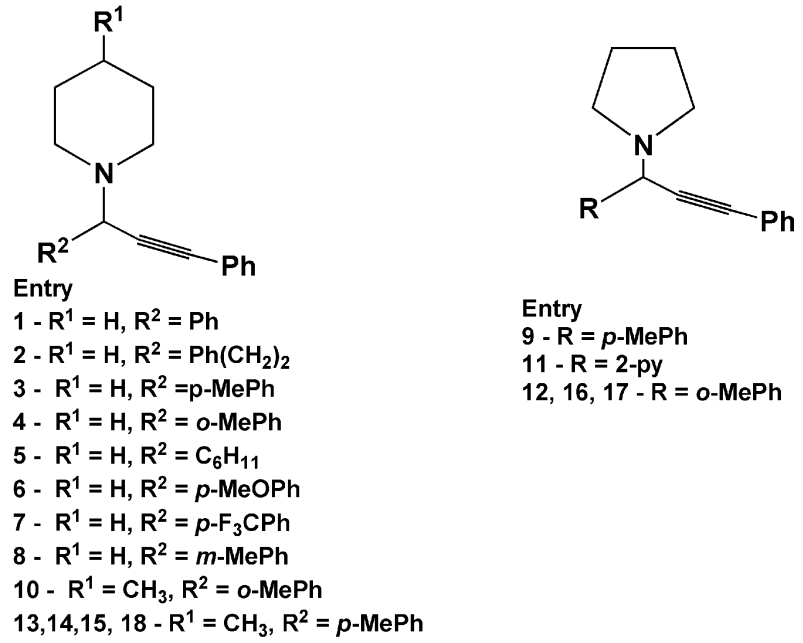

Chart 2 Reaction products from Table 3 (entries 1-18).

compound $\mathbf{2}$ in entry 15 is due to higher workup losses during the isolation of the product. Lowering the catalyst charge from 3 to $0.3 \%$ does not decrease the activity significantly (entries 13 and 14), which makes this catalyst comparable to the best catalysts described in the literature. ${ }^{12}$

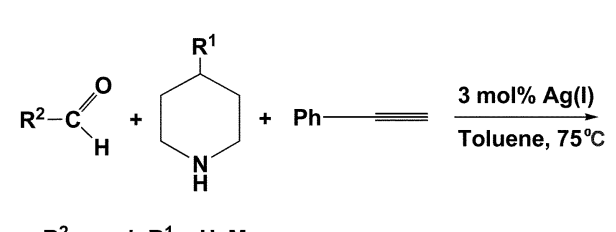<smiles>[R]C1CCN(C([R])Cc2ccccc2)CC1</smiles>

(1)

Previous experiments have shown that metallic silver does not show any catalytic activity, ${ }^{12}$ rendering therefore unlikely the possibility of a reduction of the applied complexes to $\operatorname{Ag}(0)$ during the catalytic cycle. The mechanism most likely involves the substitution of the $\mathrm{H}$ of the alkyne by an $\mathrm{Ag}(\mathrm{I})$ species, probably involving the displacement of one or more acetonitrile molecules in solution. This silver acetylide intermediate can then react with the iminium ion resulting from the reaction of aldehydes with secondary amines, regenerating the catalyst. ${ }^{16}$ Experiments to clarify the nature of the catalytically active species are currently under way in our laboratories.

\section{Conclusion}

Complexes 1-3 are easily accessible and can be obtained in high yields. The X-ray crystal structure of compound 2 (bearing only two acetonitrile ligands) was determined and its features compared with the X-ray crystal structure of compound 1 (having four, more weakly coordinated acetonitrile ligands), which was determined recently and with closely related $\mathrm{Cu}(\mathrm{I})$ complexes. Compounds $\mathbf{1}-\mathbf{3}$ have proven to be effective catalysts for the coupling reaction of phenylalkyne, aldehydes, and amines in toluene at $75{ }^{\circ} \mathrm{C}$ without using co-catalysts or additives. Yields up to $98 \%$ can be achieved.

\section{Experimental}

All preparations and manipulations were carried out under argon atmosphere using standard Schlenk techniques. Methylene chloride was distilled over calcium hydride, $n$-hexane distilled over $\mathrm{Na}$-benzophenone and kept over $4 \AA$ molecular sieves, acetonitrile dried over calcium hydride and kept over 3 $\AA$ molecular sieves. Unless otherwise stated, all the chemicals were used as received from Aldrich. The mid-IR spectra were 
recorded with a Digilab (Bio-Rad) FTS-60A interferometer using $\mathrm{HgCdTe}$ detector, the far-IR spectra were measured with a Digilab (Bio-Rad) FTS-40 interferometer using a wire mesh beam splitter, high pressure mercury source and a deuterotriglycinesulfate detector. Raman spectra were recorded with a dedicated Digilab (Bio-Rad) or a Nicolet FT-Raman 950 spectrometers. ${ }^{1} \mathrm{H}$ NMR measurements were performed on a Bruker AVANCE-DPX-400 spectrometer. Elemental analysis were measured at the Mikroanalytisches Labor of The TU München (M. Barth). The potassium precursors of compounds 1-3 were prepared according to literature procedures. ${ }^{18,22}$

\section{$\left[\mathrm{Ag}\left(\mathrm{NCCH}_{3}\right)_{4}\right]\left[\mathrm{B}\left(\mathrm{C}_{6} \mathrm{~F}_{5}\right)_{4}\right](1)$}

A dry acetonitrile $(10.0 \mathrm{ml})$ solution of silver nitrate $(0.204 \mathrm{~g}$, $1.2 \mathrm{mmol})$ was added to a $(15.0 \mathrm{ml})$ acetonitrile solution of $\mathrm{K}\left[\mathrm{B}\left(\mathrm{C}_{6} \mathrm{~F}_{5}\right)_{4}\right]^{21}(0.861 \mathrm{~g}, 1.2 \mathrm{mmol})$. A white precipitate of $\mathrm{KNO}_{3}$ began to form immediately. The reaction mixture was stirred for about $10 \mathrm{~min}$ and diethyl ether was added to accelerate precipitation. After the reaction the solution phase was removed by filtration. The filtrate was concentrated in vacuo to dryness (without heating). The solid was redissolved in dichloromethane while minimizing light exposure and the remaining $\mathrm{KNO}_{3}$ was removed by filtration. The filtrate was brought to dryness and the solid was redissolved in acetonitrile. The solution was reduced to $2.0 \mathrm{ml}$ under oil pump vacuum and kept at $-35{ }^{\circ} \mathrm{C}$. The desired product was obtained as a white crystalline solid. Yield $0.936 \mathrm{~g}(82 \%)$. Calcd. for $\mathrm{C}_{32} \mathrm{H}_{12} \mathrm{AgBF}_{20} \mathrm{~N}_{4}$ : C 40.41; H 1.27; N 5.89. Found: C 40.52; H 1.30; N 5.82\%. Selected IR $\left(\mathrm{KBr}, \mathrm{cm}^{-1}\right): \nu \mathrm{CN}, 2266,2286$ ${ }^{1} \mathrm{H}$ NMR (400 MHz, $\left.\mathrm{CDCl}_{3}, \mathrm{rt}, \delta(\mathrm{ppm})\right) 2.07\left(\mathrm{CH}_{3}, \mathrm{~s}, 12 \mathrm{H}\right)$.

\section{$\left[\mathrm{Ag}\left(\mathrm{NCCH}_{3}\right)_{2}\right]\left[\mathrm{B}\left\{\mathrm{C}_{6} \mathrm{H}_{3}\left(\mathrm{CF}_{3}\right)_{2}\right\}_{4}\right]$ (2)}

Silver nitrate $(0.52 \mathrm{~g}, 3.06 \mathrm{mmol})$ was dissolved in $10 \mathrm{ml}$ dry acetonitrile and the solution added to a solution of $\mathrm{K}\left[\mathrm{B}\left\{\mathrm{C}_{6} \mathrm{H}_{3}\left(\mathrm{CF}_{3}\right)_{2}\right\}_{4}\right]^{21}(2.76 \mathrm{~g}, 3.06 \mathrm{mmol})$ in acetonitrile. A white precipitate of $\mathrm{KNO}_{3}$ formed immediately. The reaction mixture was stirred for another $10 \mathrm{~min}$ and diethyl ether was added to complete precipitation. After filtration, the resulting solution was brought to dryness by oil pump vacuum and the resulting solid redissolved in dichloromethane in darkness. The solution was layered with hexane at $-35{ }^{\circ} \mathrm{C}$ and the desired product was obtained as a white crystalline solid. Yield $2.32 \mathrm{~g}$ $(72 \%)$. Calcd. for $\mathrm{C}_{36} \mathrm{H}_{18} \mathrm{AgBF}_{24} \mathrm{~N}_{2}$ : C 41.06; H 1.75; N 2.66. Found: C 40.99; H 1.71; N 2.65\%. Selected IR $\left(\mathrm{KBr}, \mathrm{cm}^{-1}\right)$ : $\nu \mathrm{CN}, 2296 .{ }^{1} \mathrm{H}$ NMR $\left(400 \mathrm{MHz}, \mathrm{CDCl}_{3} \mathrm{rt}, \delta(\mathrm{ppm})\right): 2.03$ $\left(\mathrm{CH}_{3}, \mathrm{~s}, 12 \mathrm{H}\right), 7.65-7.78\left(\mathrm{C}_{6} \mathrm{H}_{3}, \mathrm{~s}, 12 \mathrm{H}\right)$.

\section{$\left[\mathrm{Ag}\left(\mathrm{NCCH}_{3}\right)_{4}\right]\left[\left(\mathrm{C}_{6} \mathrm{~F}_{5}\right)_{3} \mathrm{~B}-\mathrm{C}_{3} \mathrm{H}_{3} \mathrm{~N}_{2}-\mathrm{B}\left(\mathrm{C}_{6} \mathrm{~F}_{5}\right)_{3}\right](3)$}

A dry acetonitrile $(14.0 \mathrm{ml})$ solution of silver nitrate $(0.352 \mathrm{~g}$, $2.07 \mathrm{mmol})$ was added to a $(20.0 \mathrm{ml})$ acetonitrile solution of $\mathrm{K}\left[\left(\mathrm{C}_{6} \mathrm{~F}_{5}\right)_{3} \mathrm{~B}-\mathrm{C}_{3} \mathrm{H}_{3} \mathrm{~N}_{2}-\mathrm{B}\left(\mathrm{C}_{6} \mathrm{~F}_{5}\right)_{3}\right]{ }^{18}$ (2.343 g, $\left.2.07 \mathrm{mmol}\right)$. A white precipitate of $\mathrm{KNO}_{3}$ formed immediately. The reaction mixture was stirred for another $10 \mathrm{~min}$ and diethyl ether was added to complete precipitation. After filtration, the resulting solution was brought to dryness by oil pump vacuum and the resulting solid redissolved in dichloromethane in darkness The remaining $\mathrm{KNO}_{3}$ was removed by filtration, the filtrate was again evaporated to dryness, redissolved in acetonitrile, vacuumed to $4.0 \mathrm{ml}$ and kept at $-35^{\circ} \mathrm{C}$. The desired product was obtained as a white crystalline solid. Yield $2.20 \mathrm{~g}(78 \%)$. Calcd. for $\mathrm{C}_{47} \mathrm{H}_{15} \mathrm{AgBF}_{30} \mathrm{~N}_{6}$ : C 41.78; $\mathrm{H}$ 1.11; $\mathrm{N}$ 6.16. Found: $\mathrm{C}$ 41.67; H 1.23; N 6.64\%. Selected IR $\left(\mathrm{KBr}, \mathrm{cm}^{-1}\right) \nu \mathrm{CN}$, 2285. ${ }^{1} \mathrm{H}$ NMR (400 MHz, $\left.\mathrm{CDCl}_{3}, \mathrm{rt}, \delta(\mathrm{ppm})\right): 2.10\left(\mathrm{CH}_{3}, \mathrm{~s}\right.$, $12 \mathrm{H}), 6.74\left(\mathrm{C}_{3} \mathrm{H}_{3}, \mathrm{~s}, 3 \mathrm{H}\right) 7.44(\mathrm{CH}, \mathrm{s}, 1 \mathrm{H})$.

\section{X-Ray single crystal structure determinations}

Preliminary examination and data collection were carried out on a KappaCCD device (NONIUS MACH3) with an Oxford Cryosystems cooling device at the window of a rotating anode (NONIUS FR591) with graphite monochromated Mo-K radiation $(\lambda=0.71073 \mathrm{~A})$. Data collection was performed using the Collect Software. ${ }^{23}$ The detector to crystal distance was $40 \mathrm{~mm}$. A correction for absorption effects and/or decay was applied during the scaling procedure. ${ }^{24}$ The structures were solved by a combination of direct methods ${ }^{25}$ and difference-Fourier syntheses. ${ }^{26}$ All non-hydrogen atoms were refined with anisotropic displacement parameters. All hydrogen atoms were found and refined with individual isotropic displacement parameters. Full-matrix least-squares refinements were carried out by minimizing $\Sigma w\left(F_{\mathrm{o}}^{2}-F_{\mathrm{c}}{ }^{2}\right)^{2}$ and converged with a maximum shift/error $<0.001$. The final difference-Fourier maps show no striking features. A disorder of two $\mathrm{CF}_{3}$ groups could be resolved clearly. The asymmetric unit cell contains two crystallographically independent molecules $\mathbf{A}$ and $\mathbf{B}$. Both are located on a centre of symmetry. CCDC reference number 258315. See http://www.rsc.org/suppdata/nj/b4/b414060e/ for crystallographic data in .cif or other electronic format.

\section{Typical procedure for coupling reactions of aldehydes, phenylacetylene and amines}

(3.0 mmol, $306.0 \mathrm{mg}$ ) phenylalkyne, $(2.2 \mathrm{mmol}, 187.0 \mathrm{mg})$ piperidine, $(2.0 \mathrm{mmol}, 224.0 \mathrm{mg})$ and $(0.06 \mathrm{mmol}, 54.0 \mathrm{mg})$

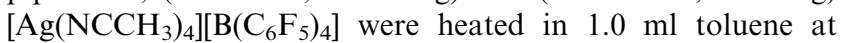
about $75{ }^{\circ} \mathrm{C}$. The product was purified by chromatography with ethyl acetate and hexane, being the yields given isolated yields. The identity of the product was proven by GC-MS and ${ }^{1} \mathrm{H}$ NMR measurements.

\section{Acknowledgements}

The DFG (Deutsche Forschungsgemeinschaft) and the FCI (Fonds der Chemischen Industrie) are acknowledged for financial support. AMS thanks the Alexander von Humboldt Foundation for a postdoctoral research grant. FEK and JM are grateful to the DAAD for financial support.

\section{References}

1 S. H. Strauss, Chem. Rev., 1993, 93, 927.

2 (a) D. H. McDaniel, Annu. Rep. Inorg. Gen. Synth., 1972, 293; (b) F. Basolo, Coord. Chem. Rev., 1968, 3, 213.

3 M. Vierle, Y. Zhang, E. Herdtweck, M. Bohnenpoll, O. Nuyken and F. E. Kühn, Angew. Chem., Int. Ed., 2003, 42, 1307.

4 Y. W. Yared, S. L. Miles, R. Bau and C. Reed, J. Am. Chem. Soc., 1977, 99, 7076.

5 R. A. Van Santen and H. P. C. E. Kuipers, Adv. Catal., 1987, 35, 265, and references therein.

6 (a) K. Burgess, H.-J. Lim, A. M. Porte and G. A. Sulikowski, Angew. Chem., Int. Ed. Engl., 1996, 35, 220; (b) H. V. R. Dias, R. G. Browing, S. A. Richey and C. J. Lovely, Organometallics, 2004, 23, 1200.

7 H. V. R. Dias, R. G. Browing, S. A. Polach, H. V. K. Diyabalanage and C. J. Lovely, J. Am. Chem. Soc., 2003, 125, 9270.

8 Y. Cui and C. He, J. Am. Chem. Soc., 2003, 125, 16202.

9 J. Cirakovic, T. G. Driver and K. A. Woerpel, J. Am. Chem. Soc., 2002, 124, 9370 .

10 N. Momoyama and H. Yamamoto, J. Am. Chem. Soc., 2003, 125, 6038.

11 N. S. Josephsohn, M. L. Snopper and A. H. Hoveyda, J. Am. Chem. Soc., 2003, 125, 4018.

12 C. Wei, Z. Li and C.-J. Li, Org. Lett., 2003, 5, 4473, and references cited therein.

13 (a) H. Liu, M. J. Calhorda, M. G. B. Drew and V. Félix, Inorg. Chim. Acta, 2003, 347, 175; (b) D. B. Llewellyn, D. Adamson and B. A. Arndtsen, Org. Lett., 2000, 2, 4165.

14 (a) F.-B. Xu, Q.-S. Li, X.-S. Zeng, X.-B. Leng and Z.-Z. Zhang, Organometallics, 2004, 23, 632; (b) V. W.-W. Yam, C.-K. Hui, 
S.-Y. Yu and N. Zhu, Inorg. Chem., 2004, 43, 812; (c) A. F. Heyduk, D. J. Krodel, E. E. Meyer and D. G. Nocera, Inorg. Chem., 2002, 41, 634.

15 N. J. Patmore, C. Hague, J. H. Cotgreave, M. F. Mahon, C. G. Frost and A. S. Weller, Chem. Eur. J., 2002, 8, 2088.

16 (a) C. M. Wei and C. J. Li, Green Chem., 2002, 4, 39; (b) C. J. Li and C. M. Wei, Chem. Commun., 2002, 268; (c) C. M. Wei, Z. G. Li and C. J. Li, Org. Lett., 2003, 5, 4473.

17 (a) M. Miura, M. Enna, K. Okuro and M. Nomura, J. Org Chem., 1995, 60, 4999; (b) R. Fassler, D. E. Frantz, J. Oetiker and E. M. Carreira, Angew. Chem., Int. Ed., 2002, 41, 3054; (c) D. E. Frantz, R. Fassler and E. M. Carreira, J. Am. Chem. Soc., 1999 121, 11245; (d) C. Fischer and E. M. Carreira, Org. Lett., 2001 3, 4319 .

18 R. E. LaPointe, G. R. Roof, K. A. Abboud and J. Klosin, J. Am Chem. Soc., 2000, 122, 9560.

19 M. Vierle, Y. Zhang, K. Köhler, C. Haeßner, A. M. Santos, E. Herdtweck, O. Nuyken and F. E. Kühn, Chem. Eur. J., 2004, 10, 6323.
20 H. C. Liang, E. Kim, C. D. Incarvito, A. L. Rheingold and K. D. Karlin, Inorg. Chem., 2002, 41, 2209.

21 R. E. Bachman and D. F. Andretta, Inorg. Chem., 1998, 37, 5657.

22 (a) B. H. Lipshutz, W. Vaccuro and B. Huff, Tetrahedron Lett., 1986, 27, 4095; (b) H. S. Kasmai, J. Chem. Educ., 1996, 76, 830; (c) F. Castellanos, J. P. Fouassier, C. Priou and J. Cavezzan, J. Appl. Polym. Sci., 1996, 60, 705.

23 Data Collection Software for NONIUS KappaCCD devices, Delft, The Netherlands, 2001.

24 Z. Otwinowski and W. Minor, in Methods in Enzymology, Vol. 276: Macromolecular Crystallography, Part A, eds. C. W. Carter Jr and R. M. Sweet, Academic Press, San Diego, CA, 1997, 307.

25 A. Altomare, G. Cascarano, C. Giacovazzo, A. Guagliardi, M. C. Burla, G. Polidori and M. Camalli, SIR92, J. Appl. Crystallogr., 1994, 27, 435.

26 G. M. Sheldrick, SHELXL-97, University of Göttingen, Germany, 1988. 